\title{
Biocontrol by Phenazine-1-carboxamide-Producing Pseudomonas chlororaphis PCL1391 of Tomato Root Rot Caused by Fusarium oxysporum f. sp. radicis-lycopersici
}

\author{
Thomas F. C. Chin-A-Woeng, ${ }^{1}$ Guido V. Bloemberg, ${ }^{1}$ Arjan J. van der Bij, ${ }^{1}$ \\ Koen M. G. M. van der Drift, ${ }^{2}$ Jan Schripsema, ${ }^{3}$ Bernadette Kroon, ${ }^{4}$ Rudy J. Scheffer, ${ }^{4}$ \\ Christoph Keel, ${ }^{5}$ Peter A. H. M. Bakker, ${ }^{6}$ Hans-Volker Tichy, ${ }^{7}$ Frans J. de Bruijn, ${ }^{8}$ \\ Jane E. Thomas-Oates, ${ }^{2}$ and Ben J. J. Lugtenberg ${ }^{1}$ \\ 'Leiden University, Institute of Molecular Plant Sciences, Clusius Laboratory, Wassenaarseweg 64, $2333 \mathrm{AL}$ \\ Leiden, The Netherlands; 'Utrecht University, Department of Mass Spectrometry, F.A.F.C. Wentgebouw, \\ Sorbonnelaan 16, 3584 CA Utrecht, The Netherlands; ${ }^{3}$ Núcleo de Pesquisas de Produtos Naturais, \\ Universidade Federal do Rio de Janeiro, Centro de Ciências da Saude, Bloco H, 21941-590-IIha do \\ Fundão, Rio de Janeiro-RJ, Brazil; ${ }^{4}$ Novartis Seeds BV, Westeinde 62, Postbus 26, 1600 AA Enkhuizen, \\ The Netherlands; ${ }^{5}$ Laboratoire de Biologie Microbienne, Université de Lausanne, $\mathrm{CH}-1015$ Lausanne, \\ Switzerland; 'Utrecht University, Department of Plant Ecology and Evolutionary Biology, Section of Plant \\ Pathology, P.O. Box 800.84, 3508 TB Utrecht, The Netherlands; ${ }^{7}$ TÜV Energie und Umwelt GmbH, \\ Niederlassung Freiburg, Robert-Bunsen Strasse 1, 79108 Freiburg i. Br., Germany; and ${ }^{8} \mathrm{MSU}-\mathrm{DOE}$ \\ Plant Research Laboratory, Michigan State University, East Lansing 48824, U.S.A. \\ Accepted 15 July 1998.
}

Seventy bacterial isolates from the rhizosphere of tomato were screened for antagonistic activity against the tomato foot and root rot-causing fungal pathogen Fusarium oxysporum f. sp. radicis-lycopersici. One isolate, strain PCL1391, appeared to be an efficient colonizer of tomato roots and an excellent biocontrol strain in an $F$. oxysporum/tomato test system. Strain PCL1391 was identified as Pseudomonas chlororaphis and further characterization showed that it produces a broad spectrum of antifungal factors (AFFs), including a hydrophobic compound, hydrogen cyanide, chitinase(s), and protease(s). Through mass spectrometry and nuclear magnetic resonance, the hydrophobic compound was identified as phenazine-1-carboxamide (PCN). We have studied the production and action of this AFF both in vitro and in vivo. Using a PCL1391 transposon mutant, with a lux reporter gene inserted in the phenazine biosynthetic operon (phz), we showed that this phenazine biosynthetic mutant was substantially decreased in both in vitro antifungal activity and biocontrol activity. Moreover, with the same mutant it was shown that the phz biosynthetic operon is expressed in the tomato rhizosphere. Comparison of the biocontrol activity of the PCN-producing strain PCL1391 with those of phenazine-1-carboxylic acid (PCA)producing strains $P$. fluorescens $2-79$ and $P$. aureofaciens 30-84 showed that the $\mathrm{PCN}$-producing strain is able to suppress disease in the tomato/F. oxysporum system,

Corresponding author: Ben J. J. Lugtenberg

E-mail: lugtenberg@ rulbim.LeigenUniv.nl whereas the PCA-producing strains are not. Comparison of in vitro antifungal activity of PCN and PCA showed that the antifungal activity of $\mathrm{PCN}$ was at least 10 times higher at neutral $\mathrm{pH}$, suggesting that this may contribute to the superior biocontrol performance of strain PCL1391 in the tomato/F. oxysporum system.

Additional keywords: microbiological control.

In recent years, various plant root-colonizing Pseudomonas spp. have been shown to be potent microbiological control agents in various plant-pathogen systems (Thomashow and Weller 1995). The use of such plant growth-promoting rhizobacteria (PGPR) is considered an addition to and an alternative for chemical pesticides, several of which are a threat to our health and environment (Lugtenberg et al. 1994). Inconsistent performance in the field has, however, delayed commercial development and general acceptance of the use of biocontrol bacteria. Therefore, more insights into the mechanisms that govern the interactions between bacteria, plant, and pathogen are needed. Biocontrol bacteria can mediate their role in disease suppression through various mechanisms including competition for nutrients and niches (Paulitz 1990), production of antimicrobial metabolites (Lugtenberg et al. 1991; Dunne et al. 1996; Keel and Defago 1997; O'Sullivan and O'Gara 1992; Thomashow and Weller 1995), and induced systemic resistance (ISR) in the host plant (van Peer et al. 1991; Leeman et al. 1995a; Pieterse et al. 1996).

Fusarium oxysporum Schlechtend.:Fr. f. sp. radicislycopersici W. R. Jarvis \& Shoemaker, the causal agent of to- 
mato foot and root rot, is responsible for substantial crop losses in commercial greenhouses in The Netherlands. Since chemical seed treatments act for only a limited period of time, microbiological control is considered a preferred strategy to control the disease. Moreover, Fusarium spp. are pathogens for many crops and biocontrol of tomato root rot can be used as a general model for diseases caused by Fusarium spp.

In this paper, we report the screening of tomato rhizosphere bacteria for in vitro antagonistic activity toward the fungal phytopathogen $F$. oxysporum f. sp. radicis-lycopersici. The most active isolate, strain PCL1391, was found able to suppress the disease substantially. Its biocontrol activity was characterized at the molecular level and found to be mediated through the production of phenazine-1-carboxamide (PCN).

\section{RESULTS}

\section{Isolation and characterization of $P$. chlororaphis strain PCL1391.}

Screening of 70 Pseudomonas strains isolated from Spanish tomato rhizosphere resulted in the identification of three isolates, PCL1391, PCL1393, and PCL1394, that displayed substantial in vitro growth inhibitory activity against $F$. oxysporum f. sp. radicis-lycopersici. The isolate PCL1391, which formed the largest growth inhibition zone, appeared to possess the best biocontrol activity in a tomato/F. oxysporum test system. In these tests, in which the 2,4-diacetylphloroglucinolproducing $P$. fluorescens strain F113 (Shanahan et al. 1992) and $P$. fluorescens strain WCS374, which can cause ISR in radish (Leeman et al. 1995a), were compared, strain PCL1391 caused a significant reduction in the number of diseased plants (Fig. 1). Based on amplified ribosomal DNA-restriction analysis and comparison with reference strains, two strains, PCL1393 and PCL1394, were identified as P. fluorescens (results not shown). With eight different restriction enzymes, it was shown that ribosomal DNA patterns of PCL1391 were identical to patterns of $P$. chlororaphis and $P$. aureofaciens (results not shown). Since strain PCL1391 produces a blue pigment after prolonged growth on $\mathrm{KB}$ agar plates, and since the orange colony coloration characteristic for $P$. aureofaciens (Krieg 1984) is absent, we conclude that strain PCL1391 belongs to the species P. chlororaphis. Strain PCL1391 is a fluorescent pseudomonad, colonies of which show a bright yellow coloration on $\mathrm{KB}$ agar and, after prolonged incubation, a green-blue pigment in the colony center. Addition of iron to the medium enhances the production of blue pigment on solid and in liquid medium. Strain PCL1391 was also able to inhibit mycelial growth of other important plant-pathogenic fungi, including Rhizoctonia solani, Botrytis cinerea, Pythium ultimum, Verticilium albo-atrum, and Alternaria dauci in a plate assay (data not shown), indicating a broad spectrum of antifungal activity. Strain PCL1391 secreted a hydrophobic antifungal compound (see below), hydrogen cyanide, chitinase(s), protease(s), lipase(s), and siderophore(s). Pyochelin, salicylic acid, phloroglucinols, pyoluteorin, glucanase, and cellulase, as determined by high-performance liquid chromatography (HPLC) and enzyme assays, were not produced by this strain.

Furthermore, strain PCL1391 was shown to be an efficient colonizer of the tomato root system since it is able to compete with the excellent rhizosphere-colonizing strain P. fluorescens
WCS365 (Simons et al. 1996). Seven days after inoculation of pre-germinated tomato seeds with equal numbers of strain PCL1391 and a Tn5-lacZ-marked derivative of strain WCS365 (van der Bij et al. 1996), analysis of the tips of 12 roots revealed the presence of equal numbers of both strains $\left(4.3 \pm 0.5 \log _{10}[\mathrm{CFU}+1] / \mathrm{cm}\right.$ of root tip and $4.4 \pm 0.4 \log _{10}$ $[\mathrm{CFU}+1] / \mathrm{cm}$ of root tip, respectively).

\section{Purification and structural identification of the hydrophobic antifungal compound produced by strain PCL1391.}

To identify compounds with antifungal properties, ironsupplemented KB medium of a 72-h culture supernatant of strain PCL1391 was extracted with toluene. After evaporation of the solvent, the residue was analyzed by silica thin layer chromatography (TLC). Antifungal activity was identified with an $F$. oxysporum TLC bioassay, and one growthinhibiting spot migrating with an $R_{f}$-value of 0.47 was detected. This spot appeared to inhibit both $F$. oxysporum spore germination and mycelial growth. To elucidate its structure, the activity was purified by HPLC analysis. The activity eluted from the HPLC column after $20.0 \mathrm{~min}$ as a single peak, and its UV spectrum (data not shown) indicated that the compound was a phenazine derivative. The active fraction was further analyzed by mass spectrometry and nuclear magnetic resonance (NMR).

The electrospray spectrum of the fraction recorded with a cone voltage of $18 \mathrm{~V}$ contained an ion at $\mathrm{m} / \mathrm{z} 224$ and a much less abundant ion at $m / z 246$, corresponding to the protonated $[\mathrm{M}+\mathrm{H}]_{+}$and the sodiated $[\mathrm{M}+\mathrm{Na}]^{+}$molecule for a compound with a molecular mass of 223 , consistent with phenazine carboxamide. In the spectrum recorded with the higher cone voltage of $53 \mathrm{~V}$, in addition to the pseudo-

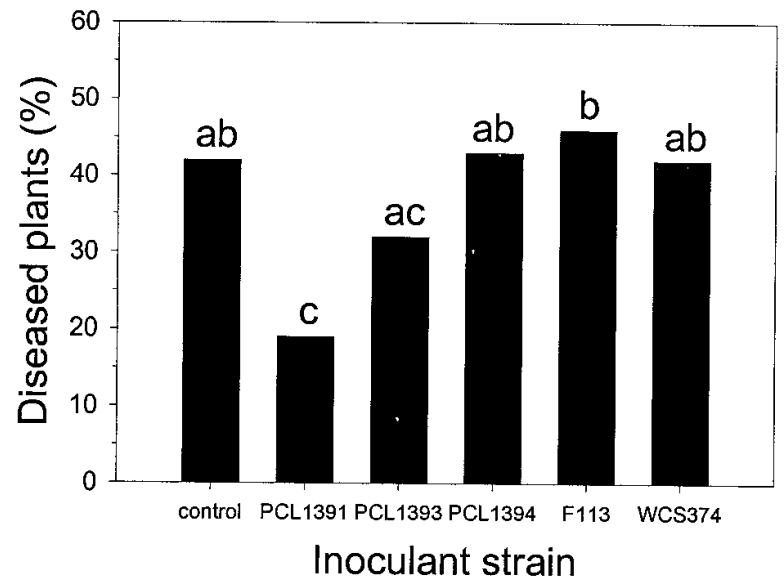

Fig. 1. Biocontrol by various Pseudomonas isolates of tomato foot rot caused by Fusarium oxysporum f. sp. radicis-lycopersici. Strains isolated from the tomato rhizosphere, PCL1391, PCL1393, PCL1394, and the $P$. fluorescens strains F113 and WCS374 were tested in an F. oxysporum/tomato test system. Bacteria were coated on pre-germinated tomato seeds, and plants were grown in potting soil infected with $F$. oxysporum spores $\left(3.0 \times 10^{6}\right.$ spores per $\left.\mathrm{kg}\right)$ under controlled conditions. Percentage of diseased plants was determined 3 weeks after inoculation. Per strain, 100 plants in 10 trays of 10 plants were tested. Data were analyzed for significance after arcsine square root transformations with analysis of variance followed by Fisher's least significant difference test $(\alpha=0.05, \mathrm{n}=10)$. Values with different letter indications denote a statistically significant difference. 
molecular ions, a very intense fragment ion was observed at $m / z$ 207, corresponding to the loss of NH3, a fragmentation typical of amide-containing compounds. A less abundant fragment ion was observed at $\mathrm{m} / z, 179$, corresponding to the protonated phenazine ring from which the carboxamide functional group has been eliminated.

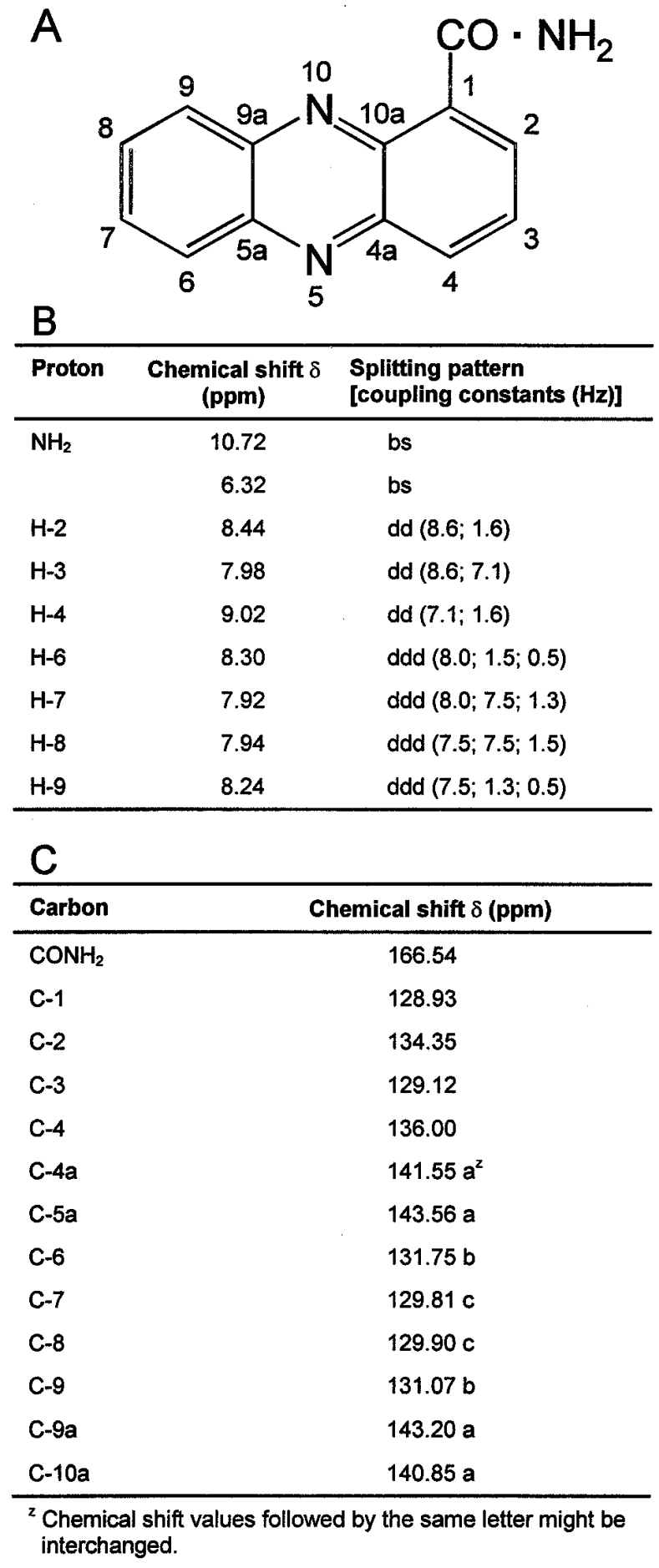

Fig. 2. Nuclear magnetic resonance (NMR) signals from phenazine-1carboxamide (PCN). A, Structure of PCN as deduced from (B) ${ }^{1} \mathrm{H}-\mathrm{NMR}$ and $(\mathbf{C}){ }^{13} \mathrm{C}$-NMR signals.
With NMR, the compound was definitively identified as PCN (Fig. 2A). The ${ }^{1} \mathrm{H}-\mathrm{NMR}$ spectrum (Fig. 2B) showed the characteristic two broad singlets for the amide protons, at $\delta$ 10.72 for the proton involved in hydrogen bonding with the aromatic nitrogen and at $\delta 6.32$ for the other proton. The position of the substituent at $\mathrm{C}-1$ appears clearly from the coupling patterns of the protons at positions 2,3 , and 4 . The ${ }^{13} \mathrm{C}-\mathrm{NMR}$ spectrum is also in full accordance with the proposed structure (Fig. 2C).

\section{Antifungal activity of PCN-nonproducing mutants of strain PCL1391.}

A PCL1391 Tn5-luxAB transposon library, consisting of 10,000 exconjugants, was screened for PCN-deficient mutants by selection for the absence of pigment production after growth on LB agar medium and in $250-\mu 1$ liquid KB cultures. In this library, three mutants, PCL1113, PCL1117, and PCL1119, were identified that are impaired in phenazine production. This was confirmed by HPLC of toluene extracts of spent growth medium. The site of the transposon insertion was determined and DNA sequence analysis of the flanking regions revealed that the transposons are inserted in homologs of the $p h z F, p h z C$, and $p h z B$ genes, respectively, which are part of the phenazine biosynthetic operon of $P$. fluorescens strain 2-79 (Mavrodi et al. 1998). Regions of 600 bp adjacent to the transposon insertions show approximately $80 \%$ homology at the nucleotide level to the genes of P. fluorescens. None of the phenazine mutants was found to be altered in $\mathrm{HCN}$, chitinase, lipase, or protease production. Neither did we detect a decrease in tomato root-colonizing ability in comparison with the wild-type strain (data not shown). In vitro microtiter plate fungal inhibition experiments show that the ability of spent growth medium of phenazine-negative mutants to inhibit growth of $F$. oxysporum was strongly reduced (Fig. 3). For mutant PCL1119, in which the $\operatorname{luxAB}$ genes of the Tn5 transposon are inserted in the same transcription direction as the phenazine biosynthetic operon, it was shown that this operon was expressed in the rhizosphere of tomato (Fig. 4).

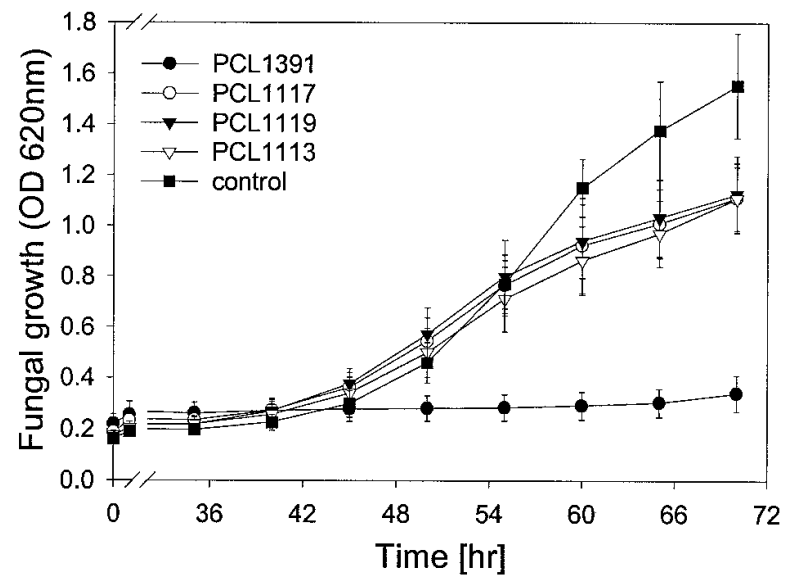

Fig. 3. In vitro antifungal activity of culture supernatants of strain PCL1391 and its phenazine biosynthetic mutants PCL1113, PCL1117, and PCL1119. Fusarium oxysporum f. sp. radicis-lycopersici was grown in the presence of spent growth medium of the bacterial strains. Fungal growth was followed by measuring increase of absorbance $\left(\mathrm{OD}_{620}\right)$ due to fungal mycelial growth. Eight replicates of each strain were tested. 


\section{Biological control of PCN production mutants of strain PCL1391.}

With the tomato/F. oxysporum foot and root rot system it was shown that the wild-type P. chlororaphis strain PCL1391 is able to reduce the number of diseased plants from $78 \%$ in the untreated control to $33 \%$ (Fig. 5). Strain PCL1119, a PCL1391 derivative impaired in PCN biosynthesis, did not suppress disease formation. Likewise, of the two other PCN biosynthetic mutants, strain PCL1113 and PCL1117 carrying transposon insertions in the $p h z F$ and $p h z C$ genes of the bio-

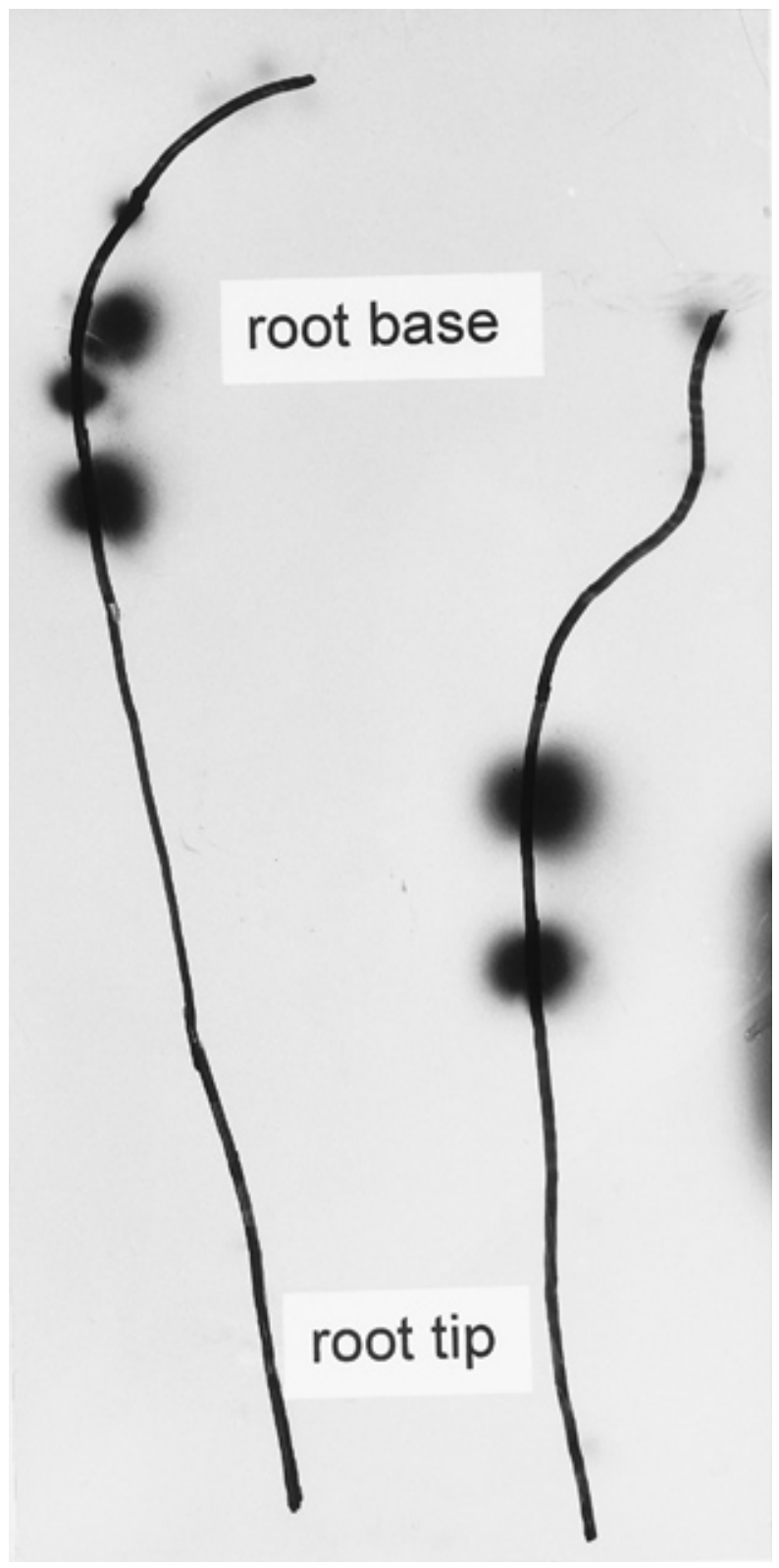

Fig. 4. Expression of the phenazine biosynthetic operon in the rhizosphere of tomato. Autoradiograph of two tomato roots grown for 7 days in a gnotobiotic sand system after inoculation with strain PCL1119 harboring promoterless $\operatorname{lu} x A B$ genes inserted in the $p h z B$ gene of the phenazine biosynthetic operon. Bacteria were inoculated on pregerminated tomato seeds and seedlings were grown in a gnotobiotic sand system. After 7 days, roots were removed from the sand, and light was detected after addition of $n$-decyl aldehyde as a substrate. Position of the complete plant root is indicated by a black line. synthetic operon, respectively, neither was able to suppress disease formation (data not shown). In the same experiment, the biocontrol activities of the phenazine-1-carboxylic acid (PCA)-producing strain P. fluorescens 2-79 (Thomashow and Weller 1988), and P. aureofaciens 30-84 (Pierson and Thomashow 1992) were tested. No significant biocontrol activity was observed for either of these strains in the tomato/F. oxysporum test system (Fig. 5).

\section{Influence of $\mathrm{pH}$ on in vitro antifungal activity of $\mathrm{PCN}$ and PCA.}

The antifungal activities of PCN and PCA were compared in an in vitro 96-well microtiter plate bioassay with $F$. oxysporum spores and HPLC-purified PCN from spent culture medium of strain PCL1391 and PCA from P. fluorescens 2-79 (Thomashow and Weller 1988). Equimolar concentrations of HPLC-purified phenazine antibiotics were serially diluted $(0.5$ to $0.02 \mu \mathrm{M}$ ) in malt extract medium and adjusted to $\mathrm{pH}$ values ranging from 3.1 to 7.0 with phosphate-citrate buffer. Within this range, growth of the fungus was not influenced by $\mathrm{pH}$ (Fig. 6B). At pH 5.7 and a concentration of $0.25 \mu \mathrm{M}$, the activity of PCN was 10 times higher than that of PCA (Fig. 6A). PCA activity was completely abolished under less acidic conditions whereas PCN exhibited antifungal activity at all of the $\mathrm{pH}$ values tested.

\section{DISCUSSION}

Strain PCL1391, the most active of the three F. oxysporum antagonistic isolates identified out of 70 tomato rhizosphere bacterial strains analyzed, was found to have a highly significant biocontrol activity against foot and root rot of tomato (Figs. 1 and 5). Further characterization showed that strain PCL1391 has broad-spectrum antifungal activity and produces a variety of potential antifungal metabolites, including a phenazine derivative, chemically characterized as PCN (Fig.

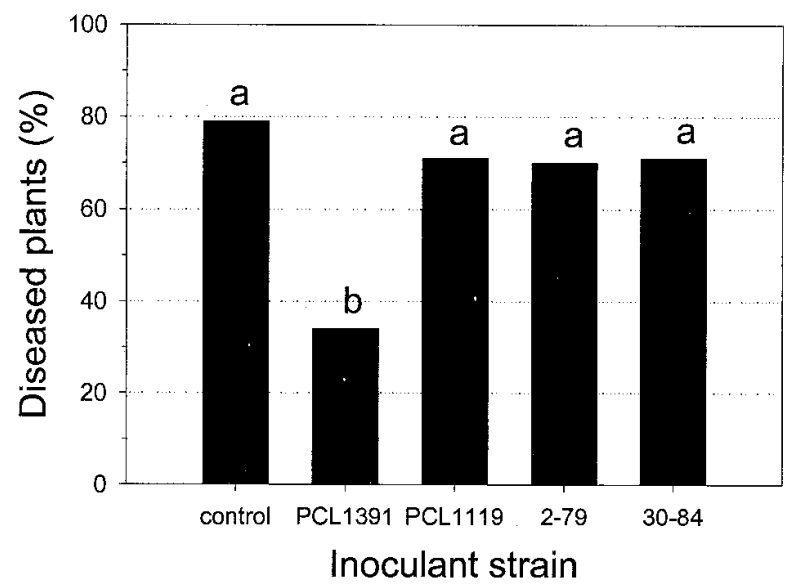

Fig. 5. Biocontrol activities of phenazine-1-carboxamide (PCN) and phenazine-1-carboxylic acid (PCA)-producing strains in biocontrol of tomato foot rot caused by Fusarium oxysporum f. sp. radicis-lycopersici. PCN-producing strain PCL1391, its phenazine biosynthetic mutant PCL1119, and PCA producers Pseudomonas fluorescens 2-79 and P. aureofaciens 30-84 were tested in an F. oxysporum/tomato test system. For experimental setup, see Figure 1 caption. Bars with the same letter are not significantly different at $\alpha=0.05, \mathrm{n}=10$, according to Fisher's least significant difference test. 
2). The use of a PCN-negative mutant, strain PCL1119, showed that PCN is involved in antifungal action, both in vitro (Fig. 3) and in disease suppression in vivo (Fig. 5). This is the first report of a Pseudomonas strain that produces PCN in which the production of this compound is shown to be crucial for biocontrol activity. Consistent with the role of PCN in biocontrol are the observations that the $p h z$ biosynthetic operon is expressed in the rhizosphere (Fig. 4) and that strain PCL1391 displays an efficient tomato root-colonizing ability.

A number of strains that have been shown to have antifungal activity in vitro do not show suppression in the tomato/ $F$. oxysporum test system used in this study. These strains include the two strains isolated from the tomato rhizosphere, PCL1393 and PCL1394, the 2,4-diacetylphloroglucinolproducing strain $\mathrm{F} 113$, the systemic resistance-inducing strain WCS374 (Leeman et al. 1995a) (Fig. 1), and the two PCAproducing Pseudomonas strains, 2-79 (Thomashow and Weller 1988) and 30-84 (Pierson and Thomashow 1992) (Fig. 5). Strains 2-79 and 30-84 produce PCA as the main phenazine compound and this metabolite has been shown to
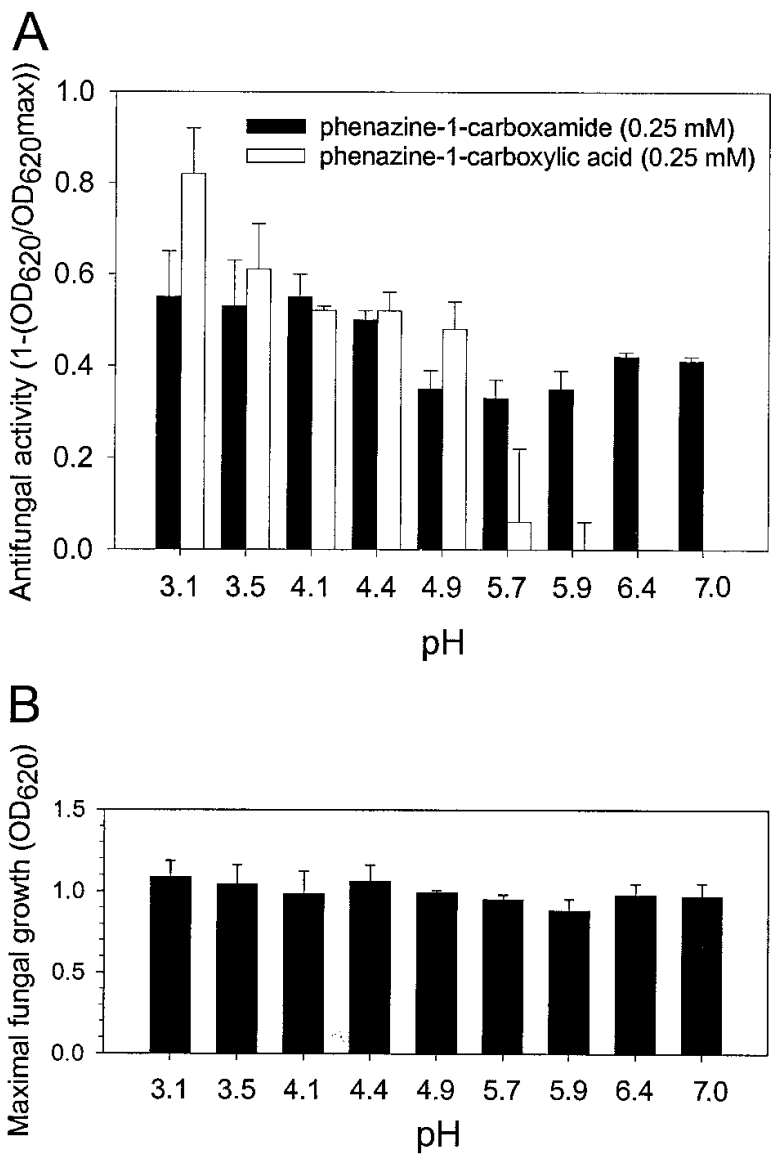

Fig. 6. Effect of $\mathrm{pH}$ on the antifungal activities of phenazine-1carboxylic acid (PCA) and phenazine-1-carboxamide (PCN). A, Effect of $\mathrm{pH}$ on the ability of PCN and PCA to inhibit growth of Fusarium oxysporum f. sp. radicis-lycopersici. F. oxysporum was grown in the presence of purified phenazine antibiotic $(0.25 \mu \mathrm{M})$ in a pH-range from 3.1 to 7.0. Mycelial growth was determined by measuring optical density at $620 \mathrm{~nm}$ after $72 \mathrm{~h}$ of incubation. B, As a control, mycelial growth of $F$. oxysporum was determined under different $\mathrm{pH}$ conditions without addition of phenazine compounds. Each condition was tested with two replicates. be involved in the suppression of take-all disease of wheat, caused by Gaeumannomyces graminis var. tritici and other fungal pathogens. Both strains inhibit growth of $F$. oxysporum in in vitro agar plate assays. These observations indicate that in vitro antifungal activity is not always correlated with in vivo biocontrol activity.

A comparison of antifungal activity of PCA and PCN by an in vitro antifungal assay (Fig. 6) showed that $\mathrm{PCN}$ remains active at $\mathrm{pH} 5.7$ and higher, at which the antagonistic activity of PCA drastically decreases. Under more acidic conditions, both derivatives have similar antifungal activity. Studies in which the PCA-producing $P$. fluorescens strain 2-79 was tested on $\mathrm{pH}$-controlled agar medium against the wheat pathogen G. graminis var. tritici gave similar results (Brisbane et al. 1987). These authors suggested that the antimicrobial activity of PCA against the wheat pathogen was related to the concentration of protonated PCA, suggesting that as the soil $\mathrm{pH}$ or rhizosphere $\mathrm{pH}$ increase, and the anionic form of PCA predominates, PCA-producing pseudomonads are less effective in biocontrol. The wider range of action of PCN can be explained by the nearly neutral carboxamide group attached to the basic ring structure, which, in contrast to PCA, will remain protonated under more basic conditions. It is therefore likely that the difference in nature of the phenazine derivatives produced contributes to the difference in biocontrol activity between the PCA-producing strains 2-79 and 30-84 and the PCN-producing strain PCL1391.

The exact functions of the genes in the phz biosynthetic operon have not yet been fully characterized, although genetic studies on the phenazine biosynthetic pathway, in which the biosynthetic operon for the main phenazine compounds was identified, have shed more light on the individual reactions in this pathway (Pierson and Thomashow 1992; Mavrodi et al. 1998, 1997). From the observations that the PCA-producing strains do not produce PCN, and that PCA can be converted to PCN by cultures of $P$. chlororaphis (Ingram et al. 1970), we expect that strain PCL1391 possesses an additional gene different from the known phenazine biosynthetic genes.

Secretion of phenazine in the culture medium by strain PCL1391 starts in the early stationary phase and reaches a maximum during the late stationary phase (data not shown). For strain 30-84, it has been shown that phenazine biosynthesis is regulated by quorum sensing (Wood and Pierson 1996). Our previous studies with scanning electron microscopy have shown that pseudomonads colonize the tomato root system as micro-colonies between the junctions of root epidermal cells (Chin-A-Woeng et al. 1997). We hypothesized that these might be the sites where quorum sensing-regulated mechanisms, such as the regulation of phenazine biosynthesis, play a role. The observation that expression of the phz operon in the tomato rhizosphere is concentrated in discrete spots on the root (Fig. 4) supports our notion that micro-colonies are the sites of PCN production.

\section{MATERIALS AND METHODS}

Microorganisms, growth conditions, and plasmids.

The microorganisms and plasmids used are listed in Table 1. Pseudomonas strains were routinely cultured in King's medium B (KB) (King et al. 1954) at $28^{\circ} \mathrm{C}$. Escherichia coli was grown in Luria-Bertani (LB) medium (Sambrook et al. 1989) 
at $37^{\circ} \mathrm{C}$. F. oxysporum f. sp. radicis-lycopersici was stock cultured on potato dextrose agar (PDA) (Difco Laboratories, Detroit, MI) and grown in Czapek-Dox liquid medium (Thom and Raper 1945) at $28^{\circ} \mathrm{C}$. Media were solidified with $1.8 \%$ agar (Difco), when necessary. Kanamycin was added to the medium to a concentration of $50 \mu \mathrm{g} / \mathrm{ml}$ when appropriate.

\section{Methods for screening and characterization of the biocontrol strains.}

Tomato plants from a commercial field near Granada, Andalusia, Spain, were kindly provided by J. Olivares. Bulk soil was removed from the root systems in order to isolate the roots and directly adhering rhizosphere soil particles. Twentyfive grams of root material was shaken at $160 \mathrm{rpm}$ in $50 \mathrm{ml}$ sterile water for $45 \mathrm{~min}$ at $28^{\circ} \mathrm{C}$ (Orbital open air shaker 35913, Lab-Line Instruments, Melrose Park, IL) and samples of the suspension were plated on KB medium containing carbenicillin $(10 \mu \mathrm{g} / \mathrm{ml})$, chloramphenicol $(12.5 \mu \mathrm{g} / \mathrm{ml})$, and cycloheximide $(200 \mu \mathrm{g} / \mathrm{ml})$. Screening for in vitro antifungal activity on $\mathrm{KB}$ agar plates against $F$. oxysporum $\mathrm{f}$. sp. radicis-lycopersici was performed by stabbing a $0.5 \times 0.5 \mathrm{~cm}$ agar plug containing the fungus in the center of an LB agar plate and inoculating the bacterial strain at a distance of $3.0 \mathrm{~cm}$ from the fungus
(Geels and Schippers 1983). Bacterial strains inhibiting mycelial growth, as evidenced by a growth inhibition zone, were selected for further characterization. In vitro inhibition of a number of other plant pathogens, including Rhizoctonia solani, Botrytis cinerea, Pythium ultimum, Verticillium alboatrum, and Alternaria dauci was performed in the same way. Strains of interest were typed by amplified ribosomal DNArestriction analysis (ARDRA), which is based on sequences encoding $16 \mathrm{~S}$ ribosomal RNA. The polymerase chain reaction (PCR) is used to amplify these DNA sequences specifically, and subsequently restriction patterns are compared with those in a data base (Williams et al. 1990; Vaneechoutte et al. 1998). Eight different restriction enzymes were used to obtain ribosomal DNA patterns and these were compared with an ARDRA data base containing 35 Pseudomonas and Comamonas spp. Identification of secreted potential antifungal metabolites was performed by previously described assays. Briefly, hydrogen cyanide (HCN) was detected by cyanide indicator paper (Castric 1975), protease with 3\% milk agar plates, $\beta$-glucanase with plates containing lichenan (Sigma, St. Louis, MO) (Walsh et al. 1995), lipase with Tween 80 agar plates (Howe and Ward 1976), chitinase with plates containing colloidal chitin (Shimahara and Takiguchi 1988), and cel-

Table 1. Microorganisms and plasmids used

\begin{tabular}{|c|c|c|}
\hline Strains and plasmids & Relevant characteristics & Reference or source \\
\hline \multicolumn{3}{|l|}{ Bacterial strains } \\
\hline PCL1391 & $\begin{array}{l}\text { Wild-type Pseudomonas chlororaphis, isolated from Spanish tomato } \\
\text { rhizosphere }\end{array}$ & This study \\
\hline PCL1393 & $\begin{array}{l}\text { Wild-type Pseudomonas fluorescens, isolated from Spanish tomato } \\
\text { rhizosphere }\end{array}$ & This study \\
\hline PCL1394 & Wild-type $P$. fluorescens, isolated from Spanish tomato rhizosphere & This study \\
\hline PCL1113 & $\begin{array}{l}\text { PCL1391 derivative in which a promoterless Tn } 5 \text {-luxAB has been in- } \\
\text { serted in a phzF homolog }\end{array}$ & This study \\
\hline PCL1117 & $\begin{array}{l}\text { PCL1391 derivative in which a promoterless Tn } 5 \text {-luxAB has been in- } \\
\text { serted in a phzC homolog }\end{array}$ & This study \\
\hline PCL1119 & $\begin{array}{l}\text { PCL1391 derivative in which a promoterless Tn } 5 \text {-luxAB has been in- } \\
\text { serted in a } p h z B \text { homolog }\end{array}$ & This study \\
\hline PCL1500 & $\begin{array}{l}\text { Tn } 5 \text {-lac } Z \text { marked derivative of the efficient root colonizing } P \text {. fluo- } \\
\text { rescens biocontrol strain WCS365 }\end{array}$ & van der Bij et al. 1996 \\
\hline $2-79$ & $\begin{array}{l}\text { P. fluorescens strain whose biocontrol activity in a Gaeumannomyces } \\
\text { graminis var. tritici/wheat system is partly due to phenazine-1- } \\
\text { carboxylic acid (PCA) production }\end{array}$ & Thomashow and Weller 1988 \\
\hline $30-84$ & $\begin{array}{l}\text { P. aureofaciens strain whose biocontrol activity in a } G \text {. graminis var. } \\
\text { tritici / wheat system is partly due to PCA production }\end{array}$ & Pierson and Thomashow 1992 \\
\hline F113 & $\begin{array}{l}\text { P. fluorescens strain whose biocontrol activity in a Pythium ulti- } \\
\text { mum/sugar beet system is partly due to } 2,4 \text {-diacetylphloroglucinol } \\
\text { production }\end{array}$ & Shanahan et al. 1992 \\
\hline WCS374 & $\begin{array}{l}P \text {. fluorescens biocontrol strain causing induced systemic resistance } \\
\text { (ISR) in radish }\end{array}$ & Leeman et al. $1995 \mathrm{a}$ \\
\hline \multicolumn{3}{|l|}{ Fungi } \\
\hline $\begin{array}{l}\text { Fusarium oxysporum f. sp. } \\
\text { radicis-lycopersici ZUM2407 }\end{array}$ & Cause of crown and root rot of tomato & IPO-DLO, Wageningen, The Netherlands \\
\hline Rhizoctonia solani 3R4FNA & Cause of damping-off and fruit rot & IPO-DLO, Wageningen, The Netherlands \\
\hline Botrytis cinerea ZUM2076 & Cause of gray mold of tomato & Novartis Seeds, Enkhuizen, The Nethe rlands \\
\hline Pythium ultimum LBOP17 & Cause of damping-off and fruit rot of tomato & IPO-DLO, Wageningen, The Netherlands \\
\hline Verticilium albo-atrum & Cause of wilt of tomato & IPO-DLO, Wageningen, The Netherlands \\
\hline Alternaria dauci ZUM2372 & Isolated from carrot seeds; pathogen of carrot & Novartis Seeds, Enkhuizen, The Nethe rlands \\
\hline \multicolumn{3}{|l|}{ Plasmids } \\
\hline pRL1063a & Plasmid harboring promoterless Tn 5-luxAB transposon & Wolk et al. 1991 \\
\hline pMP6001 & $\begin{array}{l}\text { pRL1063a-based plasmid recovered from chromosomal DNA of } \\
\text { PCL1113 after digestion with EcoRI }\end{array}$ & This study \\
\hline pMP6002 & $\begin{array}{l}\text { pRL1063a - based plasmid recovered from chromosomal DNA of } \\
\text { PCL1119 after digestion with EcoRI }\end{array}$ & This study \\
\hline pMP6003 & $\begin{array}{l}\text { pRL1063a-based plasmid recovered from chromosomal DNA of } \\
\text { PCL1117 after digestion with ClaI }\end{array}$ & This study \\
\hline
\end{tabular}


lulase with plates containing 1-carboxymethylcellulose (Hankin and Anagnostakis 1977). The presence of pyochelin, salicylic acid, phloroglucinols, and pyoluteorin was detected by HPLC analyses (Keel et al. 1992) of ethylacetate extracts of 16-, 48-, or 72-h cultures of the bacterial strain grown on KB, PDA, or malt (Oxoid, London) media.

Root tip colonization by strain PCL1391 and mutants of PCL1391 in competition with PCL1500, a Tn5-lacZ-marked derivative of $P$. fluorescens WCS365, was determined by inoculation of pre-germinated seeds with a mixture of the bacteria in a 1:1 ratio. Plants were grown in a gnotobiotic sand system as described previously (Simons et al. 1996) and, after 7 days, colonization of the root tip was analyzed by dilution plating.

\section{Purification and structural identification of} the hydrophobic antifungal compound of strain PCL1391.

After growth in $\mathrm{KB}$ broth medium supplemented with a final concentration of $100 \mu \mathrm{M} \mathrm{FeCl} 3$ for $72 \mathrm{~h}$ at $28^{\circ} \mathrm{C}$, the cellfree supernatant fluid was extracted with an equal volume of toluene and the extracts were concentrated by evaporation in vacuo. Samples were dissolved in acetonitrile and fractionated by TLC or HPLC. Silica plates (Merck, Darmstadt, Germany) were developed in a solvent mixture of butanol/acetone (90/10, vol/vol). After development, antifungal activity was detected by an $F$. oxysporum silica TLC bioassay (Keen et al. 1971). The TLC plate was dried, sprayed with an $F$. oxysporum spore suspension $\left(5 \times 10^{5} / \mathrm{ml}\right)$ in malt extract broth (Sigma), and incubated in a closed container above a layer of water for $72 \mathrm{~h}$ at $28^{\circ} \mathrm{C}$. Antifungal activity on the TLC plate was evidenced by the absence of growth of fungal mycelium.

HPLC was performed with an Alltech Hypersil ODS $5 \mu \mathrm{m}$ $250 \times 4.6 \mathrm{~mm}$ column (Alltech Associates, Deerfield, IL) and a linear 18 to $80 \%$ (vol/vol) gradient of acetonitrile in water, with $0.1 \%(\mathrm{vol} / \mathrm{vol})$ trifluoroacetic acid, and a flow rate of 1 $\mathrm{ml} / \mathrm{min}$ (Watson et al. 1986; Fernandez and Pizarro 1997). UV detection was performed with a Pharmacia RSD 2140 diode array detector (Pharmacia, Uppsala, Sweden) with wavelength scanning from 190 to $400 \mathrm{~nm}$, and 1.0-ml fractions were collected for testing antifungal activity with the $F$. oxysporum TLC bioassay. Fractions with antifungal activity were collected for mass spectrometry and NMR analyses.

Positive ion mode electrospray mass spectra were obtained with a VG Platform II single quadrupole mass spectrometer. Aliquots $(10 \mu \mathrm{l})$ of each fraction dissolved in $100 \mu \mathrm{l}$ of toluene were infused into the electrospray source in $\mathrm{ACN} / \mathrm{H}_{2} \mathrm{O}$ $(50: 50 \mathrm{vol} / \mathrm{vol})$ acidified with formic acid $(1 \% \mathrm{vol} / \mathrm{vol})$ at a flow rate of $5 \mu \mathrm{l} / \mathrm{min}$. In the positive mode, spectra were scanned at a speed of $10 \mathrm{~s}$ for $\mathrm{m} / z, 50$ to 1000 , with a cone voltage of 18 or $53 \mathrm{~V}$. Spectra were recorded and processed with the MassLynx 2.0 software.

NMR spectra were obtained on a Bruker AM 500 spectrometer operating at $500 \mathrm{MHz}$ for protons and $125 \mathrm{MHz}$ for carbon-13. Samples were dissolved in $\mathrm{CDCl}_{3}$ and the solvent signal was used as internal standard $\left(7.26 \mathrm{ppm}\right.$ for ${ }^{1} \mathrm{H}-\mathrm{NMR}$ and 77.00 ppm for ${ }^{13} \mathrm{C}-\mathrm{NMR}$ ).

\section{Isolation of mutants impaired in PCN biosynthesis.}

A Tn5 transposon library was generated with pRL1063a harboring a promoterless Tn5-luxAB transposon (Wolk et al. 1991), as described by Kragelund et al. (1995) Phenazine bio- synthetic mutants were identified by loss of pigment production when grown on LB agar or in $250 \mu$ of liquid KB cultures in 96-well microtiter plates. Regions flanking the site of the transposon insertion were recovered by digestion of chromosomal DNA with either EcoRI or ClaI and subsequent recircularization of the excised fragments by ligation. Nucleotide sequencing of the flanking regions was performed with unique primers homologous to the left $\left(5^{\prime}\right.$ TACTAGATTCAATGCTATCAATGAG 3') and right (5' AGGAGGTCACATGGAATATCAGAT $3^{\prime}$ ) ends of the Tn5 transposon. Nucleotide sequencing was performed with the Thermo Sequenase kit according to methods described by the supplier (Amersham Life Science, Cleveland, $\mathrm{OH}$ ), and sequences were analyzed with the Wisconsin Package from the Genetics Computer Group (GCG; Madison, WI).

\section{Detection of lux expression in the tomato rhizosphere.}

Expression of lux in the tomato rhizosphere was assayed in a gnotobiotic sand system (Simons et al. 1996) in which seedlings were grown after inoculation of pre-germinated tomato seeds with Tn5-luxAB-marked strains. After 7 days, the seedlings were removed from the sand and most adhering rhizosphere sand, which is virtually devoid of bacteria (Chin-AWoeng et al. 1997), was removed with sterile forceps. Subsequently, the roots were placed onto a filter paper that had been drenched in a phosphate buffer containing $0.2 \%$ (vol/vol) $n$ decyl aldehyde as a substrate for the luciferase enzyme. Light production was detected by placing a photographic film over the root for $24 \mathrm{~h}$ (de Weger et al. 1991).

\section{In vitro microtiter-plate antifungal assay.}

In vitro inhibition of $F$. oxysporum $\mathrm{f}$. $\mathrm{sp}$. radicis-lycopersici was assayed by mixing filtered spent growth medium (KB) of 16-h cultures with malt extract broth containing $0.75 \%$ low melting point agarose (FMC BioProducts, Rockland, ME) or HPLC-purified phenazine antibiotics and $1 \times 10^{3}$ spores per well in a microtiter plate (Cuppers et al. 1997). When necessary, the $\mathrm{pH}$ in the wells was altered by preparing malt extract broth in a citrate-phosphate buffer (Dawson et al. 1969) instead of in water. The plates were sealed with oxygenpermeable plate sealers (Merlin Diagnostic Systems, Rotterdam, The Netherlands) and incubated at $28^{\circ} \mathrm{C}$. The growth of the fungal mycelium was followed by measuring the optical density at $620 \mathrm{~nm}$ of the wells every hour with a microtiter plate reader (Bio-Rad, Hercules, CA) for $72 \mathrm{~h}$. Maximal fungal growth and background were determined by growing without inhibitors and without fungal spores, respectively.

\section{Biocontrol tests.}

One third of a 10-day-old PDA petri dish culture of F. oxysporum f. sp. radicis-lycopersici was homogenized and inoculated in $200 \mathrm{ml}$ of Czapek-Dox medium in a 1-liter Erlenmeyer flask. After growth for 3 days at $28^{\circ} \mathrm{C}$ under shaking (110 rpm; Orbital open air shaker 3591-3, Lab-Line Instruments), the fungal material was placed on top of sterile glass wool and the filtrate was adjusted to a concentration of $5 \times$ $10^{5}$ spores $/ \mathrm{ml}$. For inoculation, spores were mixed thoroughly with potting soil $\left(3.0 \times 10^{6}\right.$ spores per $\left.\mathrm{kg}\right)$.

Tomato (Lycopersicon esculentum Mill.) seeds (cv. Carmello) were coated with bacteria by dipping the seeds in a mixture of $1 \%(\mathrm{wt} / \mathrm{vol})$ methylcellulose (Sigma) and $1 \times 10^{9}$ 
$\mathrm{CFU} / \mathrm{ml}$ bacteria in phosphate-buffered saline (PBS) buffer (Leeman et al. 1995b). Coated seeds were dried in a sterile air stream. The number of bacteria recovered from the coated seeds after shaking the bacteria into PBS, followed by dilution plating onto $\mathrm{KB}$ medium, was approximately $1 \times 10^{4} \mathrm{CFU} /$ seed. In a pot containing $25 \mathrm{~g}$ of soil (Jongkind grond, Aalsmeer, The Netherlands), one seed was sown per pot at a depth of approximately $1.5 \mathrm{~cm}$. One hundred plants were tested per treatment in series of 10 plants in order to be able to apply statistical analysis to the results. Seedlings were grown in a greenhouse at $21^{\circ} \mathrm{C}, 70 \%$ relative humidity, and $16 \mathrm{~h}$ of daylight. Plants were watered from the bottom. The number of diseased plants was determined when a substantial number of the plants in the untreated control were diseased, usually between 14 and 21 days after sowing. Plants were removed from the soil and washed, and the plant roots were examined for foot and root rot indicated by browning and lesions. Roots without any disease symptoms were classified as healthy. Data were analyzed for significance after arcsine square root transformations with analysis of variance followed by Fisher's least significant difference test $\alpha=0.05$ ), with SAS software (SAS Institute, Cary, NC). All experiments were performed at least twice.

\section{ACKNOWLEDGMENTS}

We thank John F. Bol and Aad Wesseling of the virology section of our institute for use of plant growth facilities and technical assistance, respectively. We thank Claartje Phoelich for performing the root tip colonization experiments and Stanley Brul for teaching us the use of the microwell antifungal test system. We also thank Peter Wolk for providing pRL1063a. This work was partly supported by a grant from the EU Biotech Programme (IMPACT, contract no. B102-CT93-0053) to B. J. J. L. The Tn5-luxAB library establishment and initial screening experiments were supported by a U.S. Department of Energy grant (DOE-FG 0290ER 20021) to F. J. d. B. and a Talent-stipendium of the Netherlands Organization of Scientific Research to G. V. B. J. S. was supported by CNPq, Brazil.

\section{LITERATURE CITED}

Brisbane, P. G., Janik, L. J., Tate, M. E., and Warren, R. F. O. 1987. Revised structure for the phenazine antibiotic from Pseudomonas fluorescens 2-79 (NRRL B-15132). Antimicrob. Agents Chemother. 31: 1967-1971.

Castric, P. A. 1975. Hydrogen cyanide, a secondary metabolite of Pseudomonas aeruginosa. Can. J. Microbiol. 21:613-618.

Chin-A-Woeng, T. F. C., de Priester, W., van der Bij, A. J., and Lugtenberg, B. J. J. 1997. Description of the colonization of a gnotobiotic tomato rhizosphere by Pseudomonas fluorescens biocontrol strain WCS365, using scanning electron microscopy. Mol. Plant-Microbe Interact. 10:79-86.

Cuppers, H. G. A. M., Oomes, S., and Brul, S. 1997. A model for the combined effects of temperature and salt concentration on growth rate of food spoilage molds. Appl. Environ. Microbiol. 63:3764-3769.

Dawson, M. J., Elliot, D. C., Elliot, W. H., and Jones, K. M. 1969. Data for biochemical research. Clarendon Press, Oxford.

de Weger, L. A., Dunbar, P., Mahafee, W. F., Lugtenberg, B. J. J., and Sayler, G. 1991. Use of bioluminescence markers to detect Pseudomonas spp. in the rhizosphere. Appl. Environ. Microbiol. 57:36413644.

Dunne, C., Delaney, I., Fenton, A., Lohrke, S., Moënne-Loccoz, Y., and O'Gara, F. 1996. The biotechnology and application of Pseudomonas inoculants for the biocontrol of phytopathogens. Pages 441-448 in: Biology of Plant Microbe Interactions. G. Stacey, B. Mullin, and P. M. Gresshoff, eds. International Society for Molecular Plant-Microbe Interactions, St. Paul, MN.
Fernandez, R. O., and Pizarro, R. A. 1997. High performance liquid chromatographic analysis of Pseudomonas aeruginosa phenazines. J. Chromatogr. 771:99-104

Geels, F. P., and Schippers, G. 1983. Selection of antagonistic fluorescent Pseudomonas spp. and their root colonization and persistence following treatment of seed potatoes. Phytopathol. Z. 108:193-206.

Hankin, L., and Anagnostakis, S. L. 1977. Solid media containing carboxymethylcellulose to detect $\mathrm{CX}$ cellulose activity of microorganisms. J. Gen. Microbiol. 98:109-115.

Howe, T. R., and Ward, J. M. 1976. The utilization of Tween 80 as carbon source by Pseudomonas. J. Gen. Microbiol. 92:234-235.

Ingram, J. M., and Blackwood, A. C. 1970. Microbial production of phenazines. Adv. Microb. Physiol. 13:267

Keel, C., and Defago, G. 1997. Interactions between beneficial soil bacteria and root pathogens: Mechanisms and ecological impact. Pages 27-46 in: Multitrophic Interactions in Terrestrial Systems. A. C. Gange and V. K. Brown, eds.. Blackwell Scientific, Oxford.

Keel, C., Schnider, U., Maurhofer, M., Voisard, C., Laville, J., Burger, U., Wirthner, P., Haas, D., and Défago, G. 1992. Suppression of root diseases by Pseudomonas fluorescens CHA0: Importance of the bacterial secondary metabolite 2,4-diacetylphloroglucinol. Mol. PlantMicrobe Interact. 5:4-13.

Keen, N. T., Sims, J. J., Erwin, D. C., Rice, E., and Partridge, J. E. 1971. 6-a-hydroxyphaseollin: An antifungal chemical induced in soybean hypocotyls by Phytophthora megasperma var. sojae. Phytopathology 61:1084-1089.

King, E. O., Ward, M. K., and Raney, D. E. 1954. Two simple media for the demonstration of pyocyanin and fluorescein. J. Lab. Clin. Med. 44:301-307.

Kragelund, L., Christoffersen, B., Nybroe, O., and de Bruijn, F. J. 1995. Isolation of lux reporter gene fusions in Pseudomonas fluorescens DF57 inducible by nitrogen or phosphorus starvation. FEMS Microbiol. Lett. 17:95-106.

Krieg, N. R. 1984. Bergey's Manual of Systematic Bacteriology. Vol. 1. Williams \& Wilkins, Baltimore, MD.

Leeman, M., Van Pelt, J. A., Den Ouden, F. M., Heinsbroek, M., Bakker, P. A. H. M., and Schippers, B. 1995a. Induction of systemic resistance against Fusarium wilt of radish by lipopolysaccharides of Pseudomonas fluorescens. Phytopathology 85:1021-1027.

Leeman, M., Van Pelt, J. A., Hendrickx, M. J., Scheffer, R. J., Bakker, P. A. H. M., and Schippers, B. 1995b. Biocontrol of Fusarium wilt of radish in commercial greenhouse trials by seed treatment with $\mathrm{Pseu}$ domonas fluorescens WCS374. Phytopathology 85:1301-1305.

Lugtenberg, B. J. J., de Weger, L. A., and Bennett, J. W. 1991. Microbial stimulation of plant growth and protection from disease. Curr. Opin. Biotechnol. 2:457-464.

Lugtenberg, B. J. J., de Weger, L. A., and Schippers, B. 1994. Bacterization to protect seed and rhizosphere against disease. Pages 293-302 in: Seed Treatment: Progress and Prospects. T. Martin, ed. British Crop Protection Council, Farnham, UK.

Mavrodi, D. V., Ksenzenko, V. N., Bonsall, R. F., Cook, R. J., Boronin, A. M., and Thomashow, L. S. 1998. A seven-gene locus for synthesis of phenazine-1-carboxylic acid by Pseudomonas fluorescens 2-79. J. Bacteriol. 180:2541-2548.

Mavrodi, D. V., Ksenzenko, V. N., Chatuev, B. M., Thomashow, L. S., and Boronin, A. M. 1997. Structural and functional organization of Pseudomonas fluorescens genes encoding enzymes of phenazine-1carboxylic acid biosynthesis. Mol. Biol. 31:62-68.

O'Sullivan, D. J., and O'Gara, F. 1992. Traits of fluorescent Pseudomonas spp. involved in suppression of plant root pathogens. Microbiol. Rev. 56:662-676.

Paulitz, T. C. 1990. Biochemical and ecological aspects of competition in biological control. Pages 713-724 in: New Direction in Biological Control: Alternatives for Suppressing Agricultural Pests and Diseases. R. Baker and P. E. Dunn, eds. Liss, Chicago.

Pierson, L. S., III, and Thomashow, L. S. 1992. Cloning and heterologous expression of the phenazine biosynthetic locus from Pseudomonas aureofaciens 30-84. Mol. Plant-Microbe Interact. 5:330-339.

Pieterse, C. M. J., van Wees, S. C. M., Hoffland, E., Vanpelt, J. A., and van Loon, L. C. 1996. Systemic resistance in Arabidopsis induced by biocontrol bacteria is independent of salicylic acid accumulation and pathogenesis related gene expression. Plant Cell 8:1225-1237.

Sambrook, J., Fritsch, E. F., and Maniatis, T. A. 1989. Molecular Cloning: A Laboratory Manual. 2nd ed. Cold Spring Harbor Laboratory, 
Cold Spring Harbor, NY.

Shanahan, P., O'Sullivan, D. J., Simpson, P., Glennon, J. D., and O'Gara, F. 1992. Isolation of 2,4-diacetylphloroglucinol from a fluorescent pseudomonad and investigation of physiological parameters influencing its production. Appl. Environ. Microbiol. 58:353-358.

Shimahara, K., and Takiguchi, Y. 1988. Preparation of crustacean chitin. Pages 417-423 in: Methods in Enzymology. W. A. Wood and S. T. Kellog, eds. Academic Press, San Diego, CA

Simons, M., van der Bij, A. J., Brand, J., de Weger, L. A., Wijffelman, C. A., and Lugtenberg, B. J. J. 1996. Gnotobiotic system for studying rhizosphere colonization by plant growth-promoting Pseudomonas bacteria. Mol. Plant-Microbe Interact. 9:600-607.

Thom, C., and Raper, K. B. 1945. Manual of the Aspergilli. Williams \& Wilkins, Baltimore, MD.

Thomashow, L. S., and Weller, D. M. 1988. Role of a phenazine antibiotic from Pseudomonas fluorescens in biological control of Gaeumannomyces graminis var. tritici. J. Bacteriol. 170:3499-3508.

Thomashow, L. S., and Weller, D. M. 1995. Current concepts in the use of introduced bacteria for biological disease control: Mechanisms and antifungal metabolites. Pages 187-235 in: Plant-Microbe Interactions. G. Stacey and N. T. Keen, eds. Chapman \& Hall, New York.

van der Bij, A. J., de Weger, L. A., Tucker, W. T., and Lugtenberg, B. J. J. 1996. Plasmid stability in Pseudomonas fluorescens in the rhizosphere. Appl. Environ. Microbiol. 62:1076-1080. van Peer, R., Niemann, G. J., and Schippers, B. 1991. Induced resistance and phytoalexin accumulation in biological control of Fusarium wilt of carnation by Pseudomonas sp. strain WCS417r. Phytopathology 81:728-734.

Vaneechoutte, M., Boerlin, P., Tichy, H. V., Bannerman, E., Jager, B., and Bille, J. 1998. Comparison of PCR-based DNA fingerprinting techniques for the identification of Listeria species and their use for atypical Listeria isolates. Int. J. Syst. Bacteriol. 48:127-139.

Walsh, G. A., Murphy, R. A., Killeen, G. F., Headon, D. R., and Power R. F. 1995. Technical note: Detection and quantification of supplemental fungal $\beta$-glucanase activity in animal feed. J. Anim. Sci. 73: 1074-1076

Watson, D., MacDermot, J., Wilson, R., Cole, P. J., and Taylor, G. W. 1986. Purification and structural analysis of pyocyanin and 1- hydroxyphenazine. Eur. J. Biochem. 159:309-313.

Williams, J. G., Kubelik, A. R., Livak, K. J., Rafalski, J. A., and Tingey, S. V. 1990. DNA polymorphisms amplified by arbitrary primers are useful as genetic markers. Nucleic Acids Res. 18:6531-6535.

Wolk, C. P., Cai, Y., and Panoff, J. M. 1991. Use of a transposon with luciferase as a reporter to identify environmentally responsive genes in a cyanobacterium. Proc. Natl. Acad. Sci. USA 88:5355-5359.

Wood, D. W., and Pierson, L. S. 1996. The phzI gene of Pseudomonas aureofaciens 30-84 is responsible for the production of a diffusible signal required for phenazine antibiotic production. Gene 168:49-53. 